\title{
Performance Analysis of 14 MW Grid-Connected Photovoltaic System
}

\author{
Ahmed S. Kagilik ${ }^{1}$ and Abduraouf M. Tawel ${ }^{2}$
}

${ }^{1}$ Faculty of Engineering, Sabrata, Al-Zawia University, Al-Zawia-Libya. e-mail: as.kagilik@gmail.com

${ }^{2}$ Renewable Energy Authority of Libya, Ministry of Electricity and Renewable Energy

Tripoli-Libya

e-mail: Raouf.Tawil@reaol.ly

\section{حول تحليل أداي منظومة خلايا شمية بسعة 14 ميجاواط متصلة بالشبكة العامة \\ أحمد سعيد كاجليك،، و عبد الرؤوف الطويل2 \\ 1' كليتا الهندست، صبراتت. جامعت الزاويتـ الزاويتة، الجهاز التنفيذى للطاقات المتجددة. وزارة الكهرباءوالطاقات المتجددة}

المللخه : هناك توجـه للعديلد من مؤسسـات الدولت الليبيت الى وضـع مقترحات فعالت الغرض منها البحث عن امكانيت الاستفادة من التضاريس المناخيت المناسبت يْ ليبيا لبناء محطات توليد الطاقت الكهربائيت باستخدام منظومات الخلايا الشمسيت على نطاق واسـع وذات قدرات كهريائيت عاليتة. يِّ هذه الورقت تم تقديه برنامـج لمقترح مشروع توليد الطاقت الكهربائيت باستخدام منظومات الخلايا الشهسيت المتصلت بالشبكت العامت وبسعت 14 ميجاواط ذروة ِِّ مدينت هون وبإشراف الجهاز التنفيذي

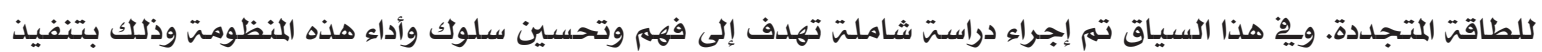
كافت مـراحل تصميمها وكذلكك تحليل أدائها الفني وبإستخلدام برنامـج حاسوب متخصص ومتتقدم وتحت الظروف المناخيت المحليت. عبر استخدام مسطحات الخلايا الشمسيت السيليكونيت المتعددة التبلر فقد تم تقدير المنتوج الطاقوي للسنت الأولى من عمل المنظومت وكذلك حساب الطاقت الكهريائيت المنتجت شهريا من هذا المثروع. من ناحيت أخرى، فقد تم حساب معامل

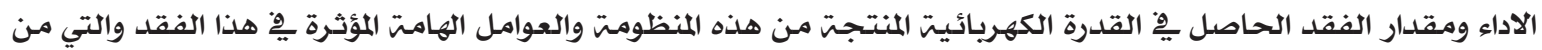
أبرزها مدى تأثير درجات الحرارة وتغير مستويات الإثعاع الشهسي والفقد ِِِّ أسـلاك التوصيل بالإضافت الى الفقد الناتج من الاستهلاك الحاصل يِّ مكونات المنظومت المختلفت. من أبرز النتائج المتحصل عليها من هذا التحليل هي أن منظومت الخلايا الشمسيت تنتج خلال السنت الاولى طاقت كهريائيت تسـاوي حوالي 24964 ميـجاواط سـاعت تزود بها الشبكت العامت والحصدول على متوسط معامل العائد السنوي بقيمتة تساوي حوالي 1783 كيلوواط سـاعت/كيلوواط ذروة بالإضافت الى المتوسط السنوي لـعامل ذسبت الأداء للـمنظومت الذي يساوي حوالي 76.9 \% ـ هذه النتائج تثبت مدلى جلدوى استخدام مصدلدر الطاقت

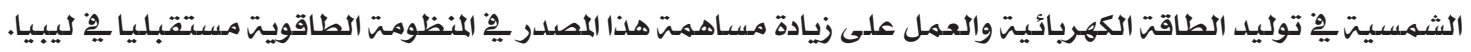

Abstract: Many Libyan authorities proposed to investigate the possibility of utilizing a suitable terrain in Libya to add generation capacity of large-scale photovoltaic power plants. In this paper, the first grid-connected PV plant of $14 \mathrm{MWp}$ which will be executed in Hoon 
city and supported by the Renewable Energy Authority of Libya (REAOL) is presented. To understand and improve the operational behavior of PV system, a comprehensive study including the plant design and detailed performance analysis under a local climate conditions is performed. Using polycrystalline silicon technology, the first year energy yield is estimated and the monthly system output for this plant is calculated. The performance ratio and various power losses (temperature, irradiance, power electronics, interconnection, etc.) are determined. The PV system supplied $24964 \mathrm{MWh}$ to the grid during the first year giving an average annual overall yield factor $1783 \mathrm{kWh} / \mathrm{kWp}$ and average annual performance ratio of the system of $76.9 \%$.

Keywords: National Program, Grid-connected PV systems, Design, System Performance.

\section{INTRODUCTION}

The world-wide demand for solar electric power or photovoltaic solar energy has grown steadily over the last decades. Therefore, the need for a reliable and low cost electric power is the primary force driving the world-wide photovoltaic (PV) industry today. The utilization of PV systems in electrical energy generation is considered as one of the most important alternative energy resources. The technological viability of solar photovoltaic systems has been proven especially for rural area applications in developing countries where solar energy is available [1].

Today, Libyan energy mix consists of local resources, such as natural gas at $38 \%$, heavy fuel oil at $20 \%$ and light fuel oil at $42 \%$ but there is no contribution from renewable energy sources in the national energy mix. Libya's energy consumption is increasing at a relatively fast rate due to population growth and economic development. Libya's high dependency on the conventional energy resources and its accelerated growth of energy demand make the development of the current energy resources and the exploitation of a broader renewable supply mix one of the country's priorities. The annual consumption of electricity has increased very rapidly over the last decade, as it increased from 1,273 GWh in 1970 with high factor and reached to about 15,000 GWh in 2000 and about 32,000 GWh in 2010 with a constant annual growth rates between 6 and 8 percent, as shown in Figure 1 [2]. In view of the future increasing demands for electricity in sustainable manner in the country, long-term energy sector roadmap was approved by the government to increase the use of the natural gas and improve the energy efficiency program. On the other hand, it should go to an alternative source for power generation, which requires no fuel and presents an opportunity for fuel consumption cost reduction to the government.

\section{SOLAR ENERGY POTENTIAL IN LIBYA}

Libya is a country where solar energy is promising for the development of its remote and isolated regions. Libya is situated between latitudes $20^{\circ}$ and $32^{\circ}$ north and longitudes $9.5^{\circ}$ and $25^{\circ}$ east. It lies within a 
high sunshine belt where the solar radiation in this area is fairly well distributed and is considered as one of the highest worldwide. The annual average of the total solar radiation reaches $7.1 \mathrm{kWh} / \mathrm{m}^{2}$ per day in coastal areas and even $8.1 \mathrm{kWh} / \mathrm{m}^{2}$ per day in its southern part; this results in 3000-3500 hours of solar irradiance annually. Therefore, the utilization of solar energy is reliable during the whole seasons.

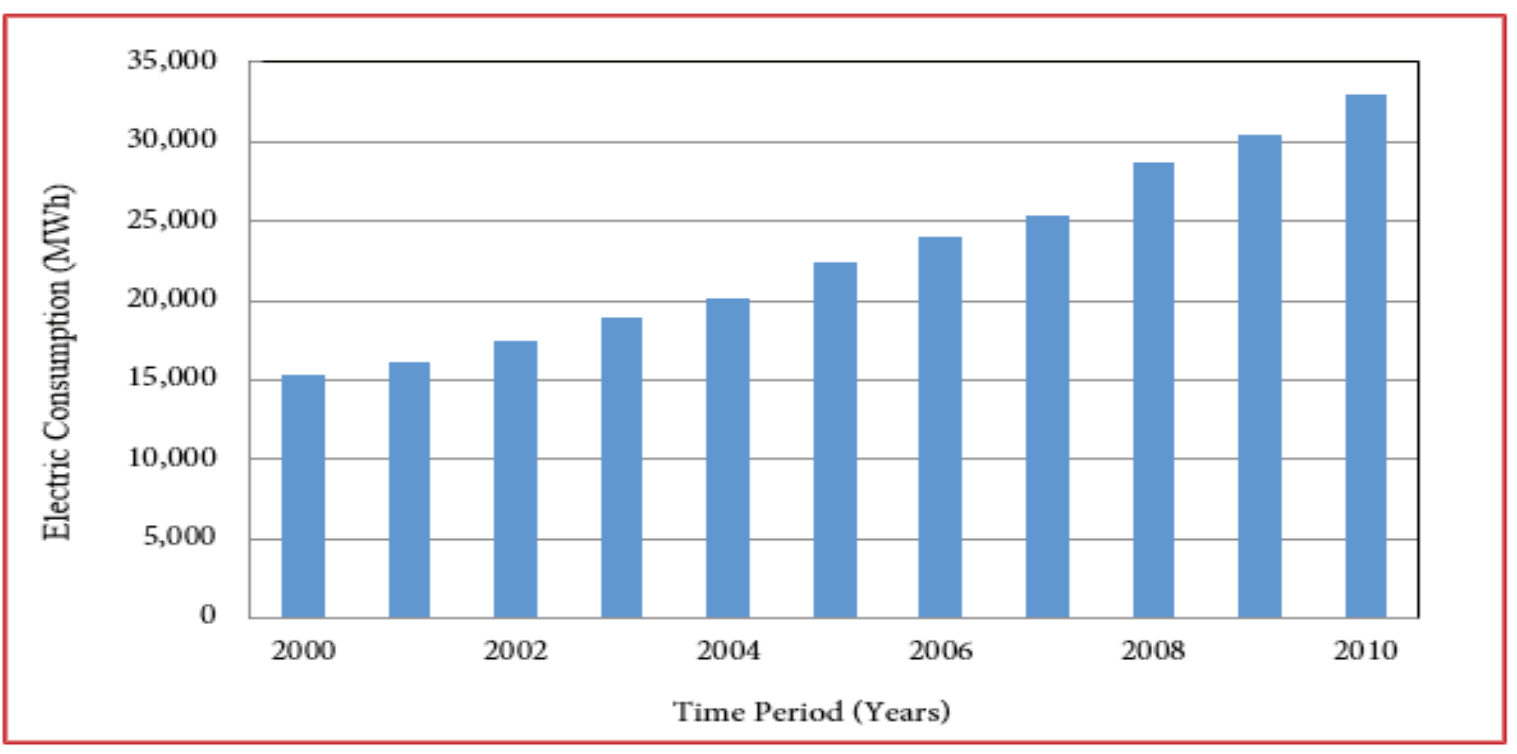

Figure (1). Annual growth of electricity consumption

Unfortunately, commercial use of photovoltaic solar energy in Libya has not been developed in proportion to its large resource base and the installed power capacity of PV systems is not exceeding $4 \mathrm{MW}$ [3]. Typical applications of PV in use today have been dominated by small stand alone power systems for rural electrification, remote telecommunication sites, water pumping and cathodic protection of oil pipes. Recently, Libya has shown large ambitions in setting renewables targets and is looking up towards a brighter future and has potent economic reasons for adopting solar energy technology. On the other hand, Libya wants to make its electrical energy system sustainable, as solar energy can present exciting business opportunities, contributing significantly to a future sustainable energy system and improving diversification of the Libyan energy production portfolio. A progress has been made with regard to solar energy regulations and the country energy strategy is improved. In this direction, a national strategic plan 2013-2025 was prepared and established for the share of solar energy generation in the total energy generation mix. It targets 7\% renewable energy share in 2020 and increasing to $10 \%$ by 2025 [3]. As a first stage of this plan, a number of large scale grid-connected PV projects with total capacity of about $90 \mathrm{MW}_{\mathrm{p}}$, beside a number of Rooftop PV systems of about $3 \mathrm{MW}_{\mathrm{p}}$ will be constructed in different sites and will be completed within the next few years. 
The Renewable Energy Authority of Libya (REAOL) is on the verge of contracting for four grid connected PV power plants to be erected in the following locations. The first project with $14 \mathrm{MW}_{\mathrm{p}} \mathrm{PV}$ system will be executed in the city of Hoon. The second project with $40 \mathrm{MW}_{\mathrm{p}}$ PV system will be executed in the city of Sebha. The third Project with $15 \mathrm{MW}_{\mathrm{p}}$ PV system will be executed in the city of Ghat. The fourth project with $15 \mathrm{MW}_{\mathrm{p}} \mathrm{PV}$ system will be executed in the city of Ghadames.

In this paper, we will present the first project with $14 \mathrm{MW}$ grid-connected PV system which will be executed in Hoon city. To understand and improve the operational behavior of this PV system, a comprehensive study including a plant design and detailed performance analysis was performed. The energy yield analysis is carried out on polycrystalline silicon technology PV systems.

\section{SITE CHARACTERISTICS AND SOLAR RADIATION}

\subsection{Site Characteristics}

From a number of sites presented for evaluation by the REAOL expert team, several suitable and promising sites located across Libya were selected for the installation of solar PV power plants due to their higher solar irradiation, flat terrain, land area availability for potential future expansion, ease of site access and proximity to distributed sub-stations and transmission network.

According to the above mentioned site characteristics, Hoon is one of suitable sites for such solar PV power projects. The Hoon project site is located at Aljofra area

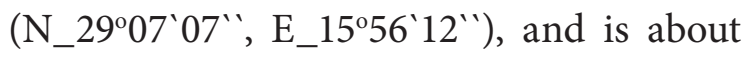
$700 \mathrm{~km}$ south east of the capital Tripoli and approximately $8 \mathrm{~km}$ east of Hoon city center. The site is easily accessible, located right next to a paved road. The total suitable area for PV plant installations amounts to approximately 20 hectares with the possibility of an additional potential area for the plant expansion at a larger stage. The site conditions can be defined as not complex, mainly flat and it is an exposed area free of any natural obstacles. The site is suitable for the installation of a PV plant, since the soil conditions is suitable because it comprises normal soil, which mostly contains sand and small rocks. An MV substation at $66 / 11 \mathrm{kV}$ levels is situated less than $8 \mathrm{~km}$ away from the site and the grid connection to the substation is possible because the capacity foreseen form the PV plant will not exceed $14 \mathrm{MW}_{\mathrm{p}}$.

\section{2- Solar Radiation}

Solar irradiance is the single most important parameter for the evaluation of PV system performance, so for simulation and evaluation purposes it is important to select the best possible data series. The global horizontal irradiation (GHI) is the most critical resource for solar PV plant. For optimum design of a PV plant, it is important to know the distribution on intensity verses wavelength. Solar maps or irradiation tables are essential tools in planning and sizing of solar energy installations. In this study we 
have tried to collect most of the available data sources for the solar climate of the project site in Hoon. However, we have to realize that all the data used in this study are based on satellite data and not on actual data collected from the site. The global horizontal irradiation data in Hoon site being used in this work for the yield simulations is based on data of Solar-Med-Atlas. The satellite database provides global irradiation on the tilted surface. The site data show that the average annual sum of GHI is above $2300 \mathrm{kWh} / \mathrm{m}^{2} /$ year, as depicted in Figure 2. From this map it is clear that the PV plant should respond to a wide range of irradiances [4].
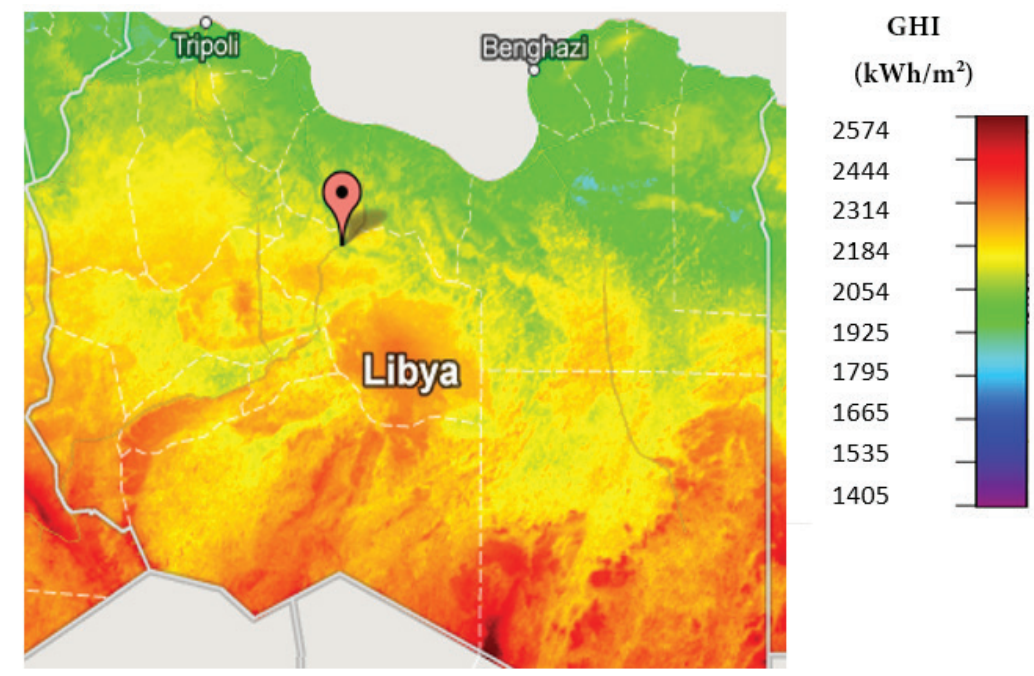

Figure (2). Annual sum of GHI on tilted surface for Hoon site.

\section{CONCEPTUAL DESIGN AND DESCRIPTION OF PHOTOVOLTAIC SYSTEM}

The design of a photovoltaic system is generally addressed to the best matching conditions between the energy supplied to the system by the sun and the energy required at the load to be fed by the system. The energy produced by a gridconnected photovoltaic system depends on (i) climatic factors (incident irradiation and module working temperature), (ii) inverter characteristics (yield, working point and operation threshold, defined as the minimum required power to connect the inverter to the grid) and (iii) the coupling system to the grid, which depends on the characteristics of the energy produced by the inverter and on grid stability and availability [5]. For designers and planners of PV systems, it is important to have an idea about critical parameters for a system performance and safety. A number of important parameters can be identified as the most important for a successful PV system design such as: the location, inclination, orientation, nominal power, system voltage, and electrical characteristics and specifications of the PV system components.

In this project, $14 \mathrm{MWp}$ solar PV power plant is optimally designed for the site in Hoon. The designed PV plant consists of 
several smaller sub-systems or arrangements with $1 \mathrm{MWp}$ each. One of the advantages of the modular approach is that the sections can either be built simultaneously or in different phases. On the other hand, the distances between rows are chosen to allow easy maintenance. The module mounting structure is fixed with an inclination angle of about $22^{\circ}$ from the horizontal and the orientation usually directed to the south.

Depending on the modules peak power output, the PV power plant can be defined. In this work, typical Poly-crystalline modules with capacity of $230 \mathrm{~W}_{\mathrm{p}}$ are chosen in the analysis. With this module power rating, the photovoltaic generator will require a total of about 60,872 modules divided to 14 modules in series and 4,348 strings in parallel.

The PV system is integrated with a special component added to the modules and constitutes of the Inverter which is used to interconnect the output of the PV generator to the electrical grid. The inverter is required to convert the DC power produced by the PV generator into AC power and to keep the voltage drop typically below $1 \%$. The typical inverter commonly used for a conceptual system design operates at $300-600 \mathrm{~V}$ with unit nominal power of $500 \mathrm{~kW}$ AC. Therefore, the number of inverters required for the whole system is equal to 28 units with total power of $14000 \mathrm{~kW}$ AC.

As a standard method, the output from the inverters is collected in a low voltage 3 -phased system which connects to step-up transformers $(400 \mathrm{~V} / 11 \mathrm{kV})$ that feed the energy into the grid. Besides the regular protection equipment located at each side of step-up transformers, switchgears are foreseen for the final connection to the grid. The cables have to be of special purpose armored cables, and should be laid in underground cable ducts to protect them from environment issues. Generally, PV systems are fully monitored to evaluate and analyze its performance with the local power grid and environment. In this monitoring system, a number of items like: DC/AC voltages and currents, AC active power, power quality, PV module surface temperature, input-output inverter data, meteorological parameters are measured and controlled.

\section{SYSTEM PERFORMANCE ANALYSIS AND YIELD ASSESSMENT}

In this paper, a solar PV system performance analysis is used to estimate the power output of the system. The performance of the grid connected PV system is estimated and the PV power plant indicators such as the energy yield (EY), yield factor (YF), capacity factor $(\mathrm{CF})$ and performance ratio (PR) are computed. EY and YF are the most important parameters for a PV gridconnected analysis for power plants. The EY is defined as the annual, monthly or daily net AC energy output of the PV array, while the YF is defined as the annual energy yield output of the PV array divided by the peak power of the installed PV system [6]. In this work, the EY analysis is carried out using polycrystalline silicon technology.

The monthly system output for Hoon 
plant is depicted in Figure 3. As can be seen, there is a significant variation in the PV electricity production and the energy production is more or less equally distributed throughout the year with about $30 \%$ change in the seasonal pattern. The first year EY from the PV array is estimated to be 24,964 MWh and the average generated MWh around the year is $2080 \mathrm{MWh}$, the highest average monthly sum of electricity production value is $2382 \mathrm{MWh}$ in March while the lowest value is $1660 \mathrm{MWh}$ in December as shown in Figure 3. The annual YF of our installation is $1783 \mathrm{kWh} / \mathrm{kW}_{\mathrm{p}}$ which demonstrates how good the project site is for the use of solar energy systems.

The performance of a PV system can be evaluated by investigating the PR. It can be considered as one of the most important performance indices to analyze and visualize the performance characteristics of a grid-connected PV system as a function of time. This dimensionless parameter characterizes the ratio between YF [in $\mathrm{kWh} / \mathrm{kW}_{\mathrm{p}}$ ] and the average incoming global irradiation [in $\mathrm{kWh} / \mathrm{m}^{2}$ ] incident on the plane of the array surface. The PR is a good indicator of the overall plant quality and operating conditions and represents the overall effect of losses in a system output due to the array temperature. Thus, it measures the effect of the ambient temperature of the system's site, incomplete utilization of the irradiation, and system component inefficiencies or failures (cabling, MPP deviation, inverter, and transformer) [7].

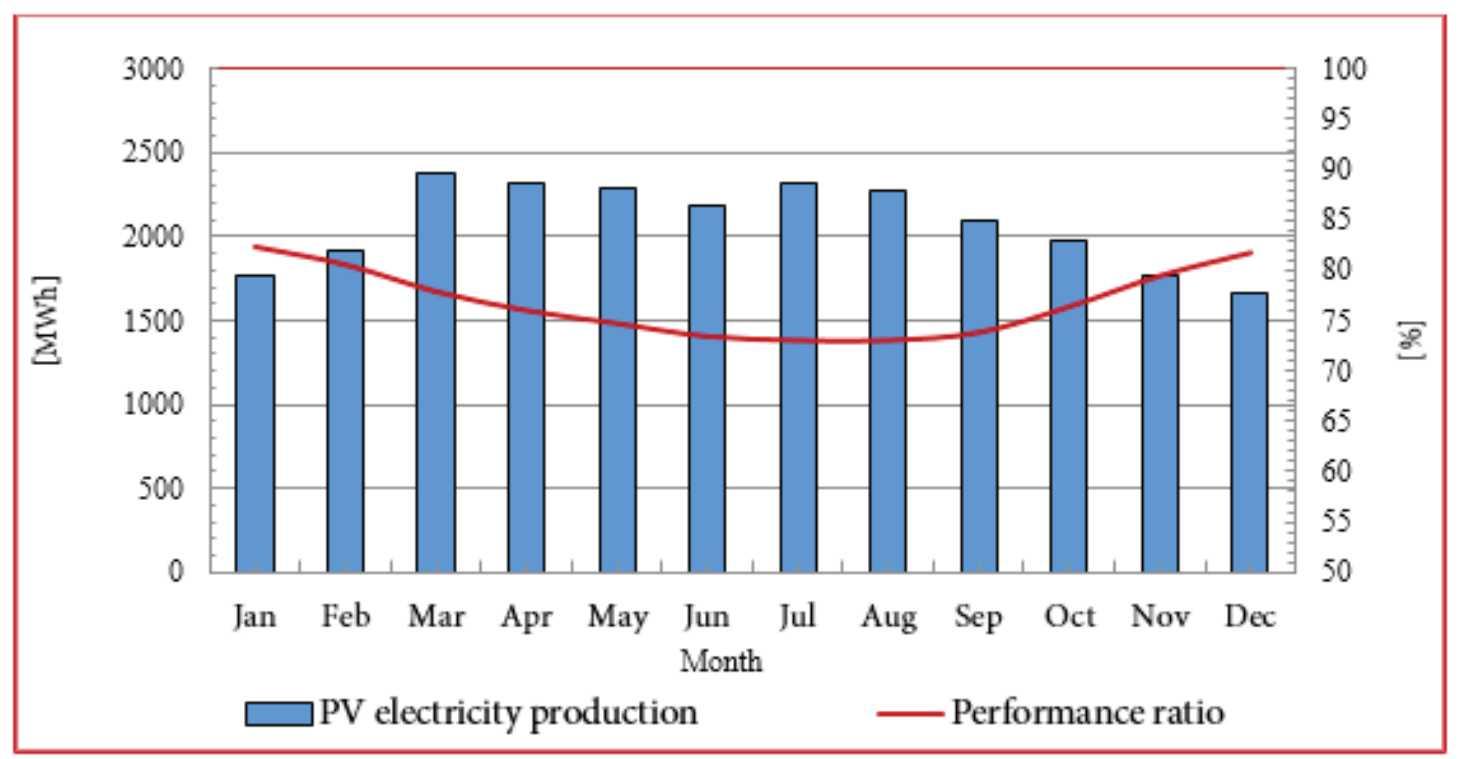

Figure (3). Monthly output and the performance ratio of the PV system

In Figure 3, the typical seasonal behavior of the PR of a polycrystalline silicon module for different irradiation levels and a wide range of temperature under real conditions is shown. It can show that the PR for the PV
Power Plant is distributed within the range $73 \%$ - 83\% metered after an inverter output. The first year over all PR is about $76.9 \%$. On the other hand, the seasonal fluctuations of climatic conditions show a large impact 
on the PR, even for well-operating systems. The relative strong dip during the summer months refer to the large temperature dependence of the used PV modules. However, this ratio allows us to compare our results with those of other grid-connected photovoltaic systems, irrespective of their location, tilt angle, orientation and nominal power. Other authors obtained values ranging between $57 \%$ and $73 \%$ for grid connected photovoltaic systems [6-8]. The performance characteristics for the first year are summarized in Table 1. These results show a huge potential of solar energy investment in Libya.

Table (1). Main Hoon project design characteristics and results

\begin{tabular}{|c|c|c|}
\hline \multicolumn{2}{|l|}{ Output } & Hoon \\
\hline Peak power & $\mathrm{MW}_{\mathrm{p}}$ & 14 \\
\hline $\begin{array}{l}\text { Average Horizontal } \\
\text { Global Irradiation }\end{array}$ & $\mathrm{kWh} / \mathrm{m}^{2}$ & 2111 \\
\hline $\begin{array}{l}\text { Average Global } \\
\text { incident in collector } \\
\text { plane }\left(22^{\circ} \text { tilt angle }\right)\end{array}$ & $\mathrm{kWh} / \mathrm{m}^{2}$ & $\sim 2333$ \\
\hline \multicolumn{3}{|c|}{ First year performance at transformer output } \\
\hline Energy yield & $\mathrm{MWh} / \mathrm{a}$ & 24964 \\
\hline Overall YF & $\mathrm{kWh} / \mathrm{kW}$ & 1783 \\
\hline Overall PR & $\%$ & 76.9 \\
\hline
\end{tabular}

Since PV system performance is strongly dependent on loss factors, therefore, it is necessary to investigate these loss factors to disseminate high quality and reliable PV system. The method presented in this paper is based to a large extent on the determination of energy losses in grid-connected PV systems by means of simulations programs. The list of energy losses covers losses in
PV systems under normal operation, i.e. it excludes energy losses due to system defects and damages. The systematic listing and description of energy losses that can occur in a grid-connected PV system is characterized by losses due to panel degradation, temperature, soiling, internal network, inverter, transformer and system availability and grid connection network [9].

The performance of PV systems is strongly dependent on meteorological conditions such as shading, irradiance and PV array surface temperature, etc. Shading losses can cause two effects: an irradiation loss and system loss. In the latter case, the energy loss is considered as a mismatch loss because the modules receive non-uniform irradiance. The single most important factor is the PV loss due to low irradiance level. It is typical for many PV modules that their efficiency decreases with decreasing irradiance. Mismatch losses are attributed to inhomogeneous irradiance at the array plane, because of shading resulting from surrounding objects, or because of differences in the orientation of parts of the array. For this reason, deviations between the shapes of the IV-curves of coupled PV modules and the larger sub-parts of the PV system occur and therefore maximum power point decreases relative to its optimum under the corresponding meteorological conditions. The temperature effect covers both the energy gain and the energy loss due to module temperatures being lower than or exceeding the STC temperature of $25^{\circ} \mathrm{C}$. This indicates that rather high temperature losses can be 
expected, as shown in Table 2. Therefore, it is recommended to select modules which have a low temperature coefficient while still having considerably high efficiency during periods of high temperatures. The losses caused by the inverter can be divided into two sources: The first one is the losses due to DC/AC energy conversion which are determined by the inverter's efficiency curve including the inverter standby energy consumption. The second is the effects resulting from the inverter control such as: the energy loss resulting from the protective cut-off procedure at high input powers, increased inverter temperatures, and the effect of the cascade coupling of a number of inverters. Dust loss and DC-cable losses are other factors that may affect the energy loss. Dust loss is a result of reduced transmission of irradiance due to the contaminated surface of PV modules, while DC-cable losses are defined as the ohmic losses in the wiring, on the assumption that parts of the PV array are uncoupled and that maximum power-point tracking is ideal.

Table (2). System losses over the whole year

\begin{tabular}{|c|c|}
\hline Item & {$[\%]$} \\
\hline \multicolumn{2}{|l|}{ PV module } \\
\hline PV loss due to irradiance level & 2.3 \\
\hline PV loss due to temperature & 13.3 \\
\hline Module array mismatch loss & 2.1 \\
\hline Ohmic wiring loss & 1.2 \\
\hline Module quality loss & 1.6 \\
\hline \multicolumn{2}{|l|}{ Inverter } \\
\hline $\begin{array}{l}\text { Inverter loss during operation } \\
\text { (efficiency) }\end{array}$ & 2.9 \\
\hline $\begin{array}{l}\text { Inverter loss due to voltage } \\
\text { threshold }\end{array}$ & 0.2 \\
\hline
\end{tabular}

\section{CONCLUSIONS}

The promotion and development of renewable energies has recently become an important priority for Libya. In this direction large scale grid-connected PV projects with total capacity of about 90 MW peak will be established as a national plan in next years. The first project with 14 MW grid-connected PV system which will be executed in Hoon city is presented and a comprehensive study including the plant design, performance analysis and behavior is performed to observe the overall effect of climatic conditions on their operation characteristics for the monitoring period.

The first year analysis performance at the transformer output is investigated and the final yield, performance ratio and the system losses are calculated. Quantification of PV system performance and losses is indicated to ensure high quality and reliable PV systems. It is found that, the average annual PV energy yield is 24,964 MWh, the average annual overall yield factor is $1783 \mathrm{kWh} / \mathrm{kW}_{\mathrm{p}}$ and the average annual performance ratio of the system is $76.9 \%$. As a conclusion, the integration of this renewable energy generation with the transmission network is satisfactory, and the results will help in demonstrating the benefits and challenges associated with facilitating the increase in the penetration levels of PV systems in the electric network in Libya.

\section{REFERENCES}

[1]. PV and Solar Market Intelligence Report, Part of Ispy publishing Industry Survey, Market 
Intelligence and Forecasts Series, Report 1 - 2013.

[2]. General Electricity Company of Libya (GECOL), annual report 2010.

[3]. "Renewable Energy in Libya", Renewable Energy Authority of Libya, annual activity report, 2012.

[4]. http://www.solar-med-atlas.org.

[5]. M. Sidrach-de-Cardona and Ll. Mora Lo'pez, Energy 24 (1999) 93-102.

[6]. Emmanuel Kymakis et al, Energy Conversion and Management, 50 (2009) 433.
[7]. Jung Hun Sol et al, 23rd European Photovoltaic Solar Energy Conference and Exhibition, 1-5 September 2008, Valencia, Spain.

[8]. Udo Rindelhardt et al, 23rd European Photovoltaic Solar Energy Conference and Exhibition, 1-5 September 2008, Valencia, Spain.

[9]. "Optimization of Design of Grid-Connected PV Systems under Danish Conditions", PV-OPT Report (final), April 2009. 